\title{
Relationship between proteome changes of Longissimus muscle and intramuscular fat content in finishing pigs fed conjugated linoleic acid
}

\author{
Weijing Zhong ${ }^{1,2}$, Zongyong Jiang ${ }^{1 *}$, Chuntian Zheng ${ }^{1 *}$, Yingcai Lin ${ }^{1}$, Lin Yang ${ }^{3}$ and Shutong Zou ${ }^{3}$ \\ ${ }^{1}$ Ministry of Agriculture Key Laboratory of Animal Nutrition and Feed Science (South China), State Key Laboratory of \\ Livestock and Poultry Breeding, Institute of Animal Science, Guangdong Academy of Agricultural Sciences, Guangzhou \\ 510640, People's Republic of China \\ ${ }^{2}$ College of Life Science, South China Normal University, Guangzhou 510631, People's Republic of China \\ ${ }^{3}$ College of Animal Science, South China Agricultural University, Guangzhou 510642, People's Republic of China \\ (Received 3 November 2009 - Revised 16 July 2010-Accepted 22 July 2010 - First published online 1 September 2010)
}

\section{Abstract}

The present experiment was conducted to determine proteome changes in Longissimus muscle of finishing pigs fed conjugated linoleic acid (CLA), in association with alteration of intramuscular fat content. Previously, seventy-two Duroc $\times$ Landrace $\times$ Large White gilts (approximately $60 \mathrm{~kg}$ ) had been fed maize-soyabean meal-based diets with $0,12.5$ and $25 \mathrm{~g}$ CLA/ kg diet. The CLA contained $369 \cdot 1 \mathrm{mg} / \mathrm{g}$ cis-9, trans -11 CLA, $374.6 \mathrm{mg} / \mathrm{g}$ trans-10, cis-12 CLA and $53.7 \mathrm{mg} / \mathrm{g}$ other isomers. Six pigs per treatment were slaughtered when they reached a body weight of approximately $100 \mathrm{~kg}$. Data published from a previous experiment demonstrated that supplementation with 12.5 or $25 \mathrm{~g} \mathrm{CLA} / \mathrm{kg}$ diet increased intramuscular fat content $(P<0.05)$. The present study investigated the proteome changes in Longissimus muscle of control and pigs supplemented with $25 \mathrm{~g}$ CLA $/ \mathrm{kg}$ diet. CLA significantly influenced the abundance of proteins related to energy metabolism, fatty acid oxidation and synthesis, amino acid metabolism, defence, transport and other miscellaneous processes $(P<0.05)$. The increase in intramuscular fat content was positively correlated with the increased abundance of carbonic anhydrase 3 and aspartate aminotransferase $(P<0.05)$. We suggest that the proteome changes in Longissimus muscle contributed to greater intramuscular lipid content in CLA-supplemented pigs.

\section{Key words: Conjugated linoleic acid: Finishing pigs: Intramuscular fat: Proteome}

Conjugated linoleic acids (CLA) are a group of geometric and positional mixtures of linoleic acid with conjugated double-bond pairs. cis-9, trans-11 CLA and trans-10, cis12 CLA are biologically active isomers ${ }^{(1)}$. Previous studies have demonstrated that CLA can reduce obesity, improve immunity and have anticarcinogenic, antiatherosis, antidiabetes properties, indicating that CLA play a versatile role in regulating metabolic pathways. Most studies have demonstrated that dietary CLA modulates energy repartition in favour of body fat reduction in finishing pigs $^{(2-8)}$. However, there have been reports that CLA did not affect or increased backfat thickness in pigs ${ }^{(9,10)}$.

Interestingly, dietary CLA was found to increase intramuscular fat content ${ }^{(4,7,8,11,12)}$, suggesting that effects of CLA on lipid metabolism varied with fat depots. However, other investigators reported either no change ${ }^{(6)}$ or even a decrease in intramuscular fat content ${ }^{(3,13)}$ in CLA-supplemented pigs. Thus, the biological effects of CLA on porcine subcutaneous and intramuscular adipose tissues as well as on skeletal muscle are probably complex. At present, mechanisms responsible for the actions of CLA are largely unknown.

Proteomics technology can simultaneously determine many proteins in tissues ${ }^{(14)}$, including pig skeletal muscle $^{(15)}$. This method is useful to identify proteins related to meat quality attributes ${ }^{(16-19)}$, pathophysiology ${ }^{(20,21)}$ and nutrient metabolism ${ }^{(22-24)}$. Therefore, this approach was employed in the present study to determine proteome changes in Longissimus muscle of finishing pigs supplemented with 0 or $25 \mathrm{~g} \mathrm{CLA} / \mathrm{kg}$ diet, which was previously shown to differ in lipid content, according to CLA treatment.

\section{Materials and methods}

Animals and diets

The care and use of all animals in the present study were approved by the Institute of Animal Science in Guangdong

Abbreviations: AMPK- $\gamma 3,5^{\prime}$-AMP-activated protein kinase subunit gamma-3; AST, aspartate aminotransferase; CA3, carbonic anhydrase 3; CLA, conjugated linoleic acid; LCFA, long-chain fatty acids; MCAD, medium-chain specific acyl-CoA dehydrogenase; SCD, stearoyl-CoA desaturase.

*Corresponding authors: Dr Z. Jiang, email jiangz38@gmail.com; C. Zheng, email zhengcht@gmail.com 
Academy of Agricultural Sciences. Animal design, growth performance and carcass data of experimental pigs have been described in a joint experiment ${ }^{(8)}$. Briefly, seventytwo Duroc $\times$ Landrace $\times$ Large White gilts, free of the halothane gene, were assigned to three treatments with six pens in each treatment and four pigs in each pen. The initial and final body weights of pigs were approximately 60 and $100 \mathrm{~kg}$, respectively (Table 2). All the pigs had free access to water and maize-soybean meal-based feed during this period. Treatments differed according to CLA supplementation in the diets. In the present experiment, only the two groups that were extremes for the content of CLA in the diet (i.e. 0 and $25 \mathrm{~g} / \mathrm{kg}$, respectively) were considered. The intermediate group supplemented with $12.5 \mathrm{~g} \mathrm{CLA} / \mathrm{kg} \mathrm{diet}{ }^{(8)}$ was abandoned to exclude the interaction between cis-9, trans-11 CLA, trans-10, cis-12 CLA and cis-9, cis-12 linoleic acid in the diets. The diets that met National Research Council-recommended nutrient requirements ${ }^{(25)}$ and compositions are listed in Table 1. All the diets were supplemented with sunflower oil containing $667.3 \mathrm{mg}$ cis-9, cis-12 linoleic acid/g fatty acids (supplied by Zhuhai Changqingshu Food Company, Limited, Zhuhai, China), and 0 (control) or $25 \mathrm{~g} / \mathrm{kg}$ CLA $(369 \cdot 1 \mathrm{mg}$ cis-9, trans-11 CLA, $374.6 \mathrm{mg}$ trans-10, cis-12 and $53.7 \mathrm{mg}$ other isomers/g fatty acids).

\section{Collection of pig tissues}

Pigs from control and $25 \mathrm{~g} / \mathrm{kg}$ dietary CLA-treated groups were randomly selected ( $n$ 6) to analyse the intramuscular fat content and muscle proteome changes. The animals were killed by electrical stunning and exsanguination. They were then scalded, dehaired, eviscerated and divided into halves. Samples of Longissimus muscle from the ninth to tenth rib were immediately obtained and frozen in liquid

Table 1. Composition of experimental diets $(\mathrm{g} / \mathrm{kg})$

\begin{tabular}{lcc}
\hline Ingredient & Control & CLA \\
\hline Maize & $627 \cdot 5$ & $627 \cdot 5$ \\
Soyabean meal (442 g/kg crude protein) & $168 \cdot 9$ & $168 \cdot 9$ \\
Wheat bran & $145 \cdot 0$ & $145 \cdot 0$ \\
CLA & 0 & $25 \cdot 0$ \\
SFO & $25 \cdot 0$ & 0 \\
Calcium hydrogen phosphate & $4 \cdot 1$ & $4 \cdot 1$ \\
Limestone & $9 \cdot 8$ & $9 \cdot 8$ \\
Lys & $1 \cdot 7$ & $1 \cdot 7$ \\
Salt & $3 \cdot 0$ & 3.0 \\
Premix & $15 \cdot 0$ & $15 \cdot 0$ \\
Total & 1000 & 1000 \\
Calculated values & & \\
Digestible energy (MJ/kg) & $13 \cdot 4$ & $13 \cdot 4$ \\
Crude protein & $150 \cdot 0$ & $150 \cdot 0$ \\
Lys & $7 \cdot 8$ & $7 \cdot 8$ \\
Ca & 5.5 & 5.5 \\
Total P & 4.8 & 4.8 \\
\hline
\end{tabular}

CLA, conjugated linoleic acid; SFO, sunflower oil.

* Providing the following per kg diet: $40 \mathrm{mg} \mathrm{Cu}$ as $\mathrm{CuSO}_{4}, 133 \mathrm{mg} \mathrm{Fe}$ as $\mathrm{FeSO}_{4}$, $145 \mathrm{mg} \mathrm{Zn}$ as $\mathrm{ZnSO}_{4}, 58 \mathrm{mg} \mathrm{Mn}$ as $\mathrm{MnSO}_{4}, 3 \mathrm{mg}$ iodine as $\mathrm{CalO}_{3}, 0.3 \mathrm{mg}$ Se as $\mathrm{NaSeO}_{3}, 858 \mu \mathrm{g}$ vitamin $\mathrm{A}, 12.5 \mu \mathrm{g}$ vitamin $\mathrm{D}_{3}, 22 \mathrm{mg}$ vitamin $\mathrm{E}, 5 \mathrm{mg}$ riboflavin, $16 \mathrm{mg}$ pantothenic acid, $0.3 \mathrm{mg}$ folic acid, $20 \mathrm{mg}$ niacin and $22 \mu \mathrm{g}$ vitamin $\mathrm{B}_{12}$.
$\mathrm{N}_{2}$ for proteomics analysis and fatty acid composition determination. Samples of Longissimus muscle from the eleventh to the last rib were collected and stored at $-20^{\circ} \mathrm{C}$ to determine the intramuscular fat content.

\section{Measurement of intramuscular fat content}

The muscle samples were minced and freeze dried to produce muscle powders. The content of intramuscular fat from these muscle powders was measured using petroleum diethyl ether extract using the Soxtec 2055 fat extraction system (Foss Tecator AB, Höganäs, Sweden) according to the Association of Official Analytical Chemists official method $991.36^{(26)}$. The boiling point of petroleum diethyl ether used in the present study was $30-60^{\circ} \mathrm{C}$.

\section{Fatty acid composition analysis}

The fatty acid composition of CLA and sunflower oil was analysed according to our previous method ${ }^{(8)}$. Each fatty acid methyl ester was determined as the percentage of a specific peak area to total fatty acid methyl ester peak areas.

\section{Main chemicals for proteome analysis}

Phenylmethanesulfonyl fluoride and trypsin were purchased from Roche Applied Sciences (Hoffmann-La Roche AG, Basel, Switzerland). Dithiothreitol, Tris, Coomassie Brilliant Blue G-250, urea, agarose and acrylamide were obtained from Bio-Rad Laboratories, Inc. (Hercules, CA, USA). Thiourea was purchased from Acros Organics Geel (Liège, Belgium). Other chemicals were obtained from Sigma (Sigma-Aldrich, St Louis, MO, USA).

\section{Two-dimensional electrophoresis}

Frozen muscle sample (approximately $1 \mathrm{~g}$ ) was crushed into powders with mortar and pestle in liquid $\mathrm{N}_{2}$. Powders (1 g) were homogenised in $3 \mathrm{ml}$ lysis buffer consisting of 8 $\mathrm{m}$-urea, 2 $\mathrm{m}$-thiourea, $65 \mathrm{~mm}-3$-((3-cholamidopropyl) dimethylammonio)- 1-propane sulfonate, $60 \mathrm{~mm}$-dithiothreitol, $40 \mathrm{~mm}$-Tris, pH 8.6, and 0.5 mm-phenylmethanesulfonyl fluoride by sonication. The solution was centrifuged at $15000 \mathrm{~g}$ for $45 \mathrm{~min}$ at $4^{\circ} \mathrm{C}$. The non-fat supernatant fluid was centrifuged at $40000 \mathrm{~g}$ for $45 \mathrm{~min}$ at $4^{\circ} \mathrm{C}$. Extracts were stored at $-80^{\circ} \mathrm{C}$ until used. Protein concentration was determined as described previously ${ }^{(27)}$, and bovine serum albumin was used as a standard.

Immobilised $\mathrm{pH}$ gradient isoelectric focusing was performed in a Protean isoelectric focusing Cell (Bio-Rad Laboratories, Inc.) using Bio-Rad ReadyStrip (17 cm, pH 3-10, non-linear), according to the manufacturer's instructions. The running program was set as described previously ${ }^{(19)}$. Low voltage $(100 \mathrm{~V})$ was gradually increased to $8000 \mathrm{~V}$ until a total of $60000 \mathrm{Vh}$. A total of $800 \mu \mathrm{g}$ protein was loaded onto the strip. Before isoelectric focusing, the 
strips were rehydrated overnight with a buffer consisting of 8 m-urea, $2 \mathrm{M}$-thiourea, $65 \mathrm{~mm}$-3-((3-cholamidopropyl) dimethylammonio)-1-propane sulfonate, $60 \mathrm{~mm}$-dithiothreitol and $40 \mathrm{~mm}$-Tris, $\mathrm{pH}$ 8.6. After completion of isoelectric focusing, the strips were equilibrated in $10 \mathrm{ml}$ equilibration solution as described previously ${ }^{(28)}$, and the second dimension SDS-PAGE was carried out in a Protean II xi Cell (Bio-Rad Laboratories, Inc.) with $12 \%$ polyacrylamide (36.5:1 ratio of acrylamide to bisacrylamide). The program was set as $12 \mathrm{~mA} /$ gel for $30 \mathrm{~min}$ and $25 \mathrm{~mA}$ until bromophenol blue reached the end of gel at $12^{\circ} \mathrm{C}$. Gels were stained by $0.1 \%$ hot Coomassie Brilliant Blue G-250 in $50 \%$ ethanol for $30 \mathrm{~min}$ and were then destained with $25 \%$ ethanol and 5\% acetic acid for $30 \mathrm{~min}$ and three times.

\section{Image analysis}

Destained gels were used immediately for image analysis or stored at $-80^{\circ} \mathrm{C}$ for future analysis. Triplicate gels from one pig sample were scanned with Image Master 2D Pt Software v5.0 (GeneBio, Amersham Biosciences, Little Chalfont, Bucks, UK) to analyse qualities and numbers of protein spots. After image scanning, two of three gels were selected according to the better protein spot pattern and higher spot number. Consequently, twelve sample gels from six pigs (two sample gels from each pig) in each treatment were obtained. The processing and quantification of the selected protein spots were performed as described previously ${ }^{(29)}$.

\section{Protein digestion and HPLC-MS/MS analysis}

Protein spots were excised with $1 \mathrm{ml}$ pipette tips and sterile blade from the gels, and were transferred to sterile $1.5 \mathrm{ml}$ Eppendorf tubes for tryptic digestion. Proteins were digested by trypsin ${ }^{(30)}$, followed by the HPLC-MS/MS analysis as described previously ${ }^{(31)}$ with some modifications. Briefly, extracts of peptides were dissolved in $20 \mu \mathrm{l}$ solution consisting of $2 \%$ acetonitrile and $0 \cdot 1 \%$ ammonia, and they were loaded into a $0.3 \times 5 \mathrm{~mm} \mathrm{C}_{18}$ micro precolumn (Agilent Technologies, Wilmington, DE, USA). The effluents entered a $75 \times 150 \mathrm{~mm} \mathrm{C}_{18}$ analysis column (Agilent Technologies), and the peptides were separated by gradient elution (2-40\% acetonitrile and $0 \cdot 1 \%$ ammonia for $20 \mathrm{~min}$ ). The MS spectra were automatically acquired by Esquire 3000 plus and processed by Esquire Data Analysis Software (version 3.1). Proteins were identified using the Ms-Fit search engine (http://pros pector.ucsf.edu/prospector/mshome.htm) against National Center for Biotechnology Information non-redundant and Swiss-Prot databases. The parameters adopted for searching were as follows: taxonomy: mammals; enzyme: trypsin; peptide tolerance: $\pm 1.2 \mathrm{Da} ; \mathrm{MS} / \mathrm{MS}$ tolerance: $\pm 0.6 \mathrm{Da}$, allowed up to one missed cleavage; peptide charge: $1+$; monoisotopic: average. The National Center for Biotechnology accession number, theoretical molecular weight/ isoelectric point, determined molecular weight/isoelectric point, molecular weight search score, fold change in the dietary CLA group, molecular function, sequence coverage and $P$ value from statistical analysis between the control and dietary CLA groups were presented to identify each protein. The molecular weight search score $\geq 50$ was considered a significant match $(P<0 \cdot 05)$. Each identified protein was annotated with its biological process in the gene ontology and AmiGO term tools, according to the source of identified protein. The proteins without gene ontology annotation were sorted according to the literatures available.

\section{Statistical analysis}

Data on intramuscular fat content were analysed by oneway ANOVA (Statistical Analysis Software version 8.1; SAS Institute, Inc., Cary, NC, USA) using treatment as the main effect ( $0 v v .25 \mathrm{~g}$ CLA $/ \mathrm{kg}$ diet$)$. Body weight was initially added as a covariate in the model; however, it was NS $(P=0.95)$ and was then removed from the final analysis. The abundance of protein spots in two-dimensional gels was analysed by $t$ test between the two treatments. Pearson correlation coefficients were calculated between the intramuscular fat content and the abundance of some protein spots (5'-AMP-activated protein kinase subunit gamma-3 (AMPK- $\gamma 3$ ), medium-chain specific acyl-CoA dehydrogenase (MCAD), carbonic anhydrase 3 (CA3), stearoyl-CoA desaturase (SCD) and aspartate aminotransferase $(\mathrm{AST}))$. Probability values $\leq 0.05$ were considered significant.

\section{Results}

\section{Carcass traits}

Feeding pigs with supplemental $25 \mathrm{~g}$ CLA $/ \mathrm{kg}$ diet resulted in a $54 \%$ greater intramuscular fat content when compared with controls at final slaughter (Table 2).

\section{The proteomes in Longissimus muscle}

After image analysis, a total of 589 (SD 41) protein spots were detected in the control gels, and 598 (SD 36) protein spots were detected in the CLA-supplemented gels. A representative pattern of protein separation is shown in Fig. 1. Compared with the control group, dietary CLA significantly affected $(P<0.05)$ the abundance of twenty-six proteins, which are marked in Fig. 1. Of these proteins, fourteen and twelve of them exhibited increased (Table 3) and decreased (Table 4) abundance, respectively. Proteins with a greater abundance were found to participate in six different biological processes, whereas those with a lower abundance were matched to four biological processes. The striking difference was observed for fatty acid oxidation that was up-regulated and for fatty acid synthesis that 
Table 2. Growth performance, intramuscular fat content and fatty acid composition in Longissimus muscle in pigs fed dietary conjugated linoleic acid (CLA)*

\begin{tabular}{|c|c|c|c|c|c|}
\hline & Control & $12.5 \mathrm{~g} / \mathrm{kg} \mathrm{CLA}$ & $25 \mathrm{~g} / \mathrm{kg}$ CLA & SEM & $P$ value \\
\hline Initial wt $(\mathrm{kg}) \dagger$ & $60 \cdot 89$ & $60 \cdot 59$ & $60 \cdot 73$ & 0.507 & 0.934 \\
\hline Final wt $(\mathrm{kg}) \dagger$ & $101 \cdot 97^{\mathrm{a}}$ & $98.51^{\mathrm{b}}$ & $99 \cdot 67^{a, b}$ & 0.985 & 0.097 \\
\hline Feed intake $(\mathrm{kg} / \mathrm{d}) \dagger$ & $2 \cdot 36^{\mathrm{a}}$ & $2 \cdot 18^{\mathrm{b}}$ & $2 \cdot 28^{a, b}$ & 0.039 & 0.039 \\
\hline Average daily gain $(\mathrm{kg} / \mathrm{d}) \dagger$ & 0.76 & 0.70 & 0.72 & 0.016 & $0 \cdot 100$ \\
\hline Intramuscular fat content (\% of wet wt)† & $1.45^{\mathrm{b}}$ & $2 \cdot 28^{a}$ & $2 \cdot 23^{\mathrm{a}}$ & 0.207 & 0.045 \\
\hline \multicolumn{6}{|l|}{ Fatty acid composition } \\
\hline cis-9, trans-11 CLA & $0.00^{c}$ & $0.57^{\mathrm{b}}$ & $1.68^{\mathrm{a}}$ & 0.128 & $<0.0001$ \\
\hline trans-10, cis-12 CLA & $0.00^{\mathrm{C}}$ & $0.31^{\mathrm{b}}$ & $0.76^{\mathrm{a}}$ & 0.065 & $<0.0001$ \\
\hline Total SFA & $43.76^{\mathrm{b}}$ & $50 \cdot 79^{a}$ & $51 \cdot 38^{\mathrm{a}}$ & 0.486 & $<0.0001$ \\
\hline Total MUFA & $40 \cdot 25^{\mathrm{a}}$ & $34 \cdot 22^{b}$ & $33 \cdot 17^{b}$ & 0.559 & $<0.0001$ \\
\hline
\end{tabular}

${ }^{a, b, c}$ Mean values with unlike superscript letters in the same line differ significantly $(P<0.05)$.

* Reference to Jiang et al. ${ }^{(8)}$.

$\dagger$ The data of initial weight and final weight were presented as means of twenty-four pigs. The data of feed intake and average daily gain were presented as six pens. The data of intramuscular fat content were presented as six pigs.

was down-regulated, respectively, in CLA-treated group $v$. controls. Transport and miscellaneous processes were shared by the two protein lists, whereas energy expenditure was found only in proteins with a greater abundance in the CLA-treated pigs than that in the controls.

By Pearson correlation analysis, it was found that the enhanced intramuscular fat content was positively correlated with the increased CA3 and AST protein abundance in Longissimus muscle (CA3, $r$ 0.774, $P=0.003$; AST, $r$ $0 \cdot 702, P=0 \cdot 011)$. No significant correlation was observed between intramuscular fat content and each of the following proteins: SCD, MCAD and AMPK- $\gamma 3(P>0.05)$.

\section{Discussion}

Results of the present study indicate that dietary supplementation with CLA increases the abundance of proteins related to energy expenditure and fatty acid oxidation. A major function of these proteins is to degrade macronutrients to provide energy. Our finding is consistent with the reports that whole-body energy expenditure is enhanced by dietary CLA in mice ${ }^{(32,33)}$ and rats ${ }^{(34)}$. Recently, Zhai et al. ${ }^{(35)}$ have demonstrated that although both cis-9, trans-11 CLA and trans-10, cis-12 CLA increased energy expenditure in cultured 3T3-L1 preadipocytes, only trans-10, cis-12 CLA has a stimulatory effect on fatty acid oxidation. In the present study performed in vivo with pigs fed a mixture of CLA isomers, we found a greater abundance in both proteins involved in energy expenditure such as creatine kinase and creatine kinase M-type playing a key role in the maintenance of energy homeostasis $^{(36,37)}$ and in the fatty acid oxidation pathway. Especially, a greater abundance in AMPK- $\gamma 3$, i.e. the predominant AMPK- $\gamma$ isoforms in white muscle, was also observed here in the muscle of pigs fed CLA, an observation that closely matches with the increase in the same protein reported in 3T3-L1 adipocytes treated with trans-10, cis-12 CLA ${ }^{(35)}$. Activation of AMPK- $\gamma 3$ alone or in heterodimerisation with $\alpha 2 / \beta 2$ forms results in oxidation of fatty acids ${ }^{(38,39)}$. MCAD is responsible for the first step of $\beta$-oxidation of fatty acids in mitochondria ${ }^{(40)}$. Notably, as demonstrated for skeletal muscle in the present study, MCAD mRNA levels were elevated in the livers of mice supplemented with CLA ${ }^{(41)}$ and in rats fed $\alpha$-linoleic acidrich diacylglycerol ${ }^{(42)}$. Likewise, Nall et al. ${ }^{(43)}$ recently found that CLA supplementation increased oxidation of fatty acids and glucose in rat liver and skeletal muscle. Thus, MCAD may play a role in mediating the effect of CLA on pigs. The CLA effects observed in the present study are, however, of a shorter magnitude than those observed in vitro for adipocyte cell line ${ }^{(35)}$, considering the lower number of spots as involved in these two pathways having a differential abundance in the present study.

Dietary CLA also enhanced protein abundance related to amino acid metabolism. Though mitochondrial AST plays

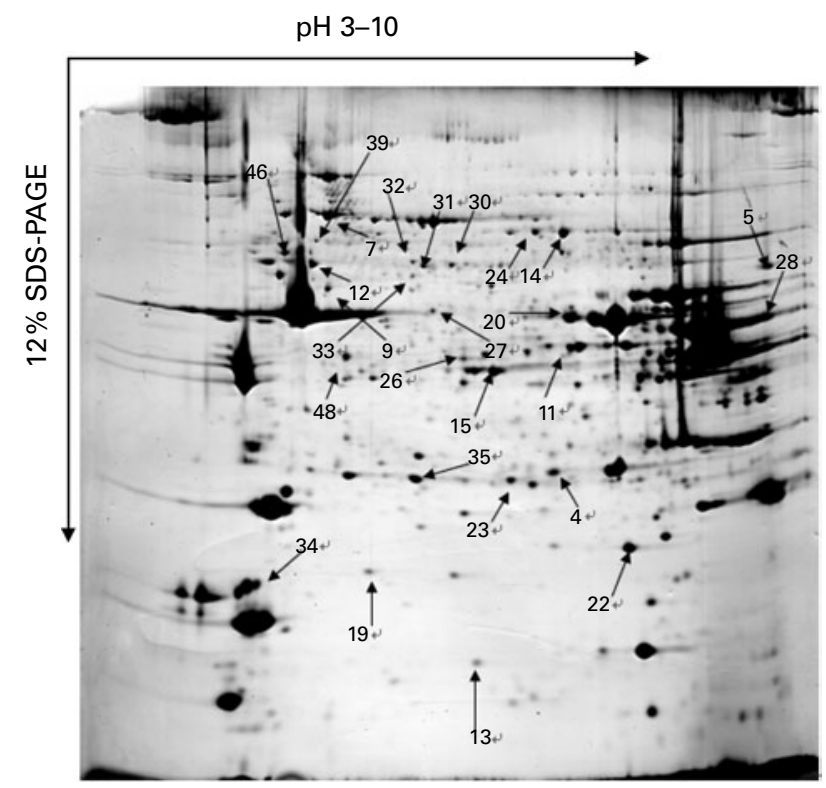

Fig. 1. Proteomic image of a representative Longissimus muscle sample from pigs fed a diet supplemented with conjugated linoleic acid ( $25 \mathrm{~g} / \mathrm{kg}$ diet). Proteins were separated by $\mathrm{pH} 3-10$ in the first dimension and $12 \%$ SDSPAGE in the second dimension. Proteins with significant changes in abundance compared with the unsupplemented control are indicated by numbers in the image. 
Table 3. Proteins with a greater abundance in pig skeletal muscle after dietary conjugated linoleic acid (CLA) supplementation

\begin{tabular}{|c|c|c|c|c|c|c|c|c|c|}
\hline No. & Identified proteins (source) & $\begin{array}{l}\text { Accession } \\
\text { no. }\end{array}$ & $\begin{array}{l}\text { Theoretical } \\
\mathrm{MW} / \mathrm{pl}\end{array}$ & $\begin{array}{l}\text { Calculated } \\
\mathrm{MW} / \mathrm{pl}\end{array}$ & SC & $\begin{array}{l}\text { MOWSE } \\
\text { score }\end{array}$ & $\begin{array}{c}\text { Fold } \\
\text { change }^{*}\end{array}$ & $P \dagger$ & Biological process GO term \\
\hline \multicolumn{10}{|c|}{ Fatty acid oxidation } \\
\hline 11 & $\begin{array}{l}\text { Medium-chain specific acyl-CoA dehydrogenase } \\
\text { (mitochondrial precursor, pig) }\end{array}$ & P41367 & $46485 / 7.03$ & $34834 / 8.02$ & 42 & 78 & 1.43 & 0.006 & Fatty acid $\beta$-oxidation \\
\hline 12 & $5^{\prime}$-AMP-activated protein kinase subunit $\gamma 3$ (pig) & Q9MYP4 & $56790 / 5 \cdot 07$ & $58884 / 5 \cdot 39$ & 39 & 67 & 1.33 & 0.025 & $\begin{array}{l}\text { Fatty acid biosynthesis and oxidation, glucose } \\
\text { transport, and glycogen biosynthesis }\end{array}$ \\
\hline \multicolumn{10}{|c|}{ Energy expenditure } \\
\hline 26 & Creatine kinase M-type (human) & P06732 & $43101 / 6 \cdot 01$ & $33884 / 6.95$ & 85 & 95 & 1.33 & 0.046 & Phosphocreatine biosynthetic process \\
\hline 28 & $\begin{array}{l}\text { Creatine kinase (sarcomeric mitochondrial } \\
\text { (precursor), bovine) }\end{array}$ & Q3ZBP1 & $47231 / 10 \cdot 27$ & $42267 / 10 \cdot 25$ & 79 & 88 & 1.50 & 0.041 & Phosphocreatine biosynthetic process \\
\hline \multicolumn{10}{|c|}{ Amino acid metabolism } \\
\hline 9 & $\begin{array}{l}\text { Ser/Thr protein phosphatase } 2 \mathrm{~A} 55 \mathrm{kDa} \text { regulatory } \\
\text { subunit } \mathrm{B} \alpha \text { isoform (fragment) (pig) }\end{array}$ & Q29090 & $49641 / 6 \cdot 41$ & $49888 / 5 \cdot 71$ & 67 & 69 & $1 \cdot 60$ & 0.037 & $\begin{array}{l}\text { Protein amino acid dephosphorylation and } \\
\text { signal transduction }\end{array}$ \\
\hline 20 & Asp aminotransferase mitochondrial precursor (pig) & P00506 & $47436 / 9 \cdot 01$ & $42267 / 8 \cdot 27$ & 45 & 56 & $2 \cdot 00$ & 0.004 & $\begin{array}{l}\text { 2-oxoglutarate, Asp, and Glu metabolic } \\
\text { processes }\end{array}$ \\
\hline \multicolumn{10}{|c|}{ Metabolism } \\
\hline 15 & Carbonic anhydrase 3 (pig) & Q5S1S4 & $29411 / 7 \cdot 78$ & $27164 / 7 \cdot 32$ & 56 & 59 & 1.50 & 0.020 & One-carbon metabolic process \\
\hline \multicolumn{10}{|c|}{ Transport } \\
\hline 7 & $\begin{array}{l}\text { Mannose-6-phosphate/insulin-like growth factor II } \\
\text { receptor (fragment) (pig) }\end{array}$ & Q95LC9 & $252552 / 5 \cdot 17$ & $102329 / 5 \cdot 96$ & 53 & 78 & $1 \cdot 27$ & 0.046 & Transport \\
\hline 39 & Albumin (rat) & Q5U3X3 & $68714 / 6 \cdot 09$ & $69502 / 5 \cdot 72$ & 32 & 57 & 1.40 & 0.002 & Respond to stress and transport \\
\hline \multicolumn{10}{|c|}{ Miscellaneous } \\
\hline 4 & Calsequestrin-2 (fragment) (pig) & P00189 & $11206 / 9 \cdot 6$ & $11858 / 8 \cdot 15$ & 39 & 53 & 1.33 & 0.027 & $\begin{array}{l}\text { Striated muscle contraction and heart } \\
\text { development }\end{array}$ \\
\hline 5 & Type $\mathrm{X}$ collagen (pig) & Q9N178 & $65447 / 9.97$ & $62230 / 10 \cdot 25$ & 41 & 348 & $1 \cdot 38$ & 0.040 & $\begin{array}{l}\text { Cartilage development and endochondral } \\
\text { ossification }\end{array}$ \\
\hline 23 & 5-Lipoxygenase-activating protein (pig) & AAA31032 & $17334 / 8 \cdot 59$ & $12883 / 7 \cdot 69$ & 76 & 50 & $1 \cdot 38$ & 0.041 & $\begin{array}{l}\text { Leukotriene biosynthetic process and protein } \\
\text { homotrimerisation }\end{array}$ \\
\hline 24 & Hairless (fragment) (pig) & AAP33389 & $37123 / 8 \cdot 87$ & $73451 / 7 \cdot 94$ & 39 & 224 & 1.33 & 0.036 & $\begin{array}{l}\text { Regulation of transcription and protein } \\
\text { hetero-oligomerisation }\end{array}$ \\
\hline 27 & Unnamed protein product (human) & CAA23753 & $69250 / 5.92$ & $44668 / 6 \cdot 62$ & 32 & 70 & 1.50 & 0.030 & Unknown \\
\hline
\end{tabular}

No., number; MW, molecular weight (Da); pl, isoelectric point; MOWSE, molecular weight search; SC, sequence coverage (\%); GO, gene ontology. * Fold change, relative volume of spot in the dietary CLA group/relative volume of spot in the control group.

$\dagger P$ value, statistical analysis between the control and dietary CLA groups. 
Table 4. Proteins with a lower abundance in pig skeletal muscle after dietary conjugated linoleic acid (CLA) supplementation

\begin{tabular}{|c|c|c|c|c|c|c|c|c|c|}
\hline No. & Identified protein (source) & $\begin{array}{l}\text { Accession } \\
\text { no. }\end{array}$ & $\begin{array}{c}\text { Theoretical } \\
\mathrm{MW} / \mathrm{pl}\end{array}$ & $\begin{array}{l}\text { Calculated } \\
\mathrm{MW} / \mathrm{pl}\end{array}$ & SC & $\begin{array}{l}\text { MOWSE } \\
\text { score }\end{array}$ & $\begin{array}{l}\text { Fold } \\
\text { change }^{*}\end{array}$ & $P \dagger$ & Biological process GO term \\
\hline \multicolumn{10}{|c|}{ Fatty acid synthesis } \\
\hline 13 & $\begin{array}{l}\text { Protein kinase, AMP-activated, } \\
\beta-1 \text { non-catalytic subunit } \\
\text { (fragment) (pig) }\end{array}$ & Q70PH1 & $3221 / 6 \cdot 86$ & $3062 / 7 \cdot 03$ & 32 & 86 & 0.57 & 0.031 & $\begin{array}{l}\text { Fatty acid and lipid biosynthetic processes, } \\
\text { respond to stress, and regulation of } \\
\text { catalytic activity }\end{array}$ \\
\hline 14 & Stearoyl-CoA desaturase (pig) & AAR87714 & $41245 / 9 \cdot 38$ & $69502 / 8 \cdot 19$ & 38 & 58 & 0.64 & 0.026 & $\begin{array}{l}\text { Fatty acid biosynthetic process and oxidation } \\
\text { reduction }\end{array}$ \\
\hline \multicolumn{10}{|c|}{ Transport } \\
\hline 30 & Serum albumin (bovine) & AAN17824 & $69278 / 5 \cdot 82$ & $62230 / 6 \cdot 70$ & 53 & 307 & 0.71 & 0.001 & Transport and negative regulation of apoptosis \\
\hline 31 & Albumin (cat) & CAD32275 & $65866 / 5 \cdot 23$ & $63973 / 6 \cdot 58$ & 74 & 145 & 0.83 & 0.002 & Respond to stress and transport \\
\hline 32 & $\begin{array}{l}\text { Chain A, X-ray study of recom- } \\
\text { binant } \\
\text { human serum albumin } \\
\text { (human) }\end{array}$ & 1UOR_A & $66358 / 5 \cdot 67$ & $62230 / 6 \cdot 54$ & 62 & 70 & 0.83 & 0.028 & Transport and negative regulation of apoptosis \\
\hline 34 & Lipocalin-1 (human) & Q5T8A1 & $19238 / 5 \cdot 39$ & $6109 / 4.89$ & 60 & 67 & 0.75 & 0.048 & Transport \\
\hline 48 & Serum albumin (mouse) & CAD29888 & $51334 / 5.49$ & $33884 / 5 \cdot 72$ & 52 & 59 & 0.67 & 0.046 & Transport and negative regulation of apoptosis \\
\hline \multicolumn{10}{|c|}{ Defence } \\
\hline $\begin{array}{c}22 \\
\text { Misce }\end{array}$ & $\begin{array}{l}\text { IL-4 (pig) } \\
\text { aneous }\end{array}$ & Q04745 & $14892 / 9 \cdot 09$ & $8054 / 8.97$ & 31 & 378 & 0.83 & 0.044 & Cellar defence response and immune response \\
\hline 19 & Calsequestrin-2 (fragment) (pig) & 018934 & $18990 / 4 \cdot 50$ & $6457 / 5 \cdot 88$ & 52 & 53 & 0.71 & 0.025 & Striated muscle contraction and heart development \\
\hline 33 & $\begin{array}{l}2 \mathrm{~d} \text { neonate thymus thymic cells } \\
\text { complementary DNA (mouse) }\end{array}$ & Q8C7C7 & $64961 / 5 \cdot 49$ & $58884 / 6 \cdot 46$ & 82 & 57 & 0.67 & 0.006 & Thymic lymphopoiesis \\
\hline 35 & Lacritin (human) & AAG44392 & $14237 / 5.43$ & $11858 / 6 \cdot 29$ & 23 & 77 & 0.75 & 0.026 & Tear secretion \\
\hline 46 & Calpastatin (human) & AAB32311 & $76573 / 4.78$ & $73451 / 5 \cdot 06$ & 55 & 69 & 0.60 & 0.048 & $\begin{array}{l}\text { Myoblast fusion and negative regulation of catalytic } \\
\text { activity }\end{array}$ \\
\hline
\end{tabular}

No., number; MW, molecular weight (Da); pl, isoelectric point; MOWSE, molecular weight search; SC, sequence coverage (\%); GO, gene ontology.

* Fold change, relative volume of spot in the dietary CLA group/relative volume of spot in the control group.
$\dagger P$ value, statistical analysis between the control and dietary CLA groups. 
an important role in amino acid metabolic process, it is also a transport protein that is identical to a plasma membranebound fatty acid-binding protein ${ }^{(44,45)}$. The greater AST abundance observed in the muscle of pigs fed the CLA mixture was also observed in 3T3-L1 cells cultured in the presence of trans-10, cis-12 CLA but not in the presence of cis-9, trans-11 CLA ${ }^{(35)}$. Some evidence suggests that plasma membrane-bound fatty acid binding protein/AST plays a role in the transmembrane movement and oxidation of long-chain fatty acids (LCFA) for energy supply ${ }^{(46)}$. It is possible that an increased abundance of AST in muscle may facilitate the entry of LCFA into muscle cells where LCFA could either undergo mitochondrial $\beta$-oxidation or be incorporated into $\mathrm{TAG}^{(47)}$. However, muscle relies predominantly on an exogenous source of $\mathrm{LCFA}^{(48)}$, due to limited intramuscular storage sites for LCFA utilisation. The exogenous LCFA may in part be derived from backfat. Unfortunately, recent studies have paid more attention to relative than absolute changes of fatty acids in muscle and backfat of pigs fed CLA ${ }^{(7-9,11)}$, which makes it difficult to postulate that exogenous LCFA were used to enhance lipid storage in muscle. In support of this hypothesis, we found a positive correlation between the intramuscular fat content and AST. Quantitative determination of the change in fatty acid content of muscle and backfat is still needed to confirm the function of AST in lipid storage.

In support of a role for CLA in stimulating intramuscular lipid accretion, the results of the present study indicate that the abundance of CA3 is increased in muscle in response to dietary CLA supplementation. CA3 catalyses the hydration of $\mathrm{CO}_{2}$ to generate bicarbonate and hydrogen ions for enhancement of fatty acid synthesis and for maintenance of $\mathrm{pH}$ homeostasis. Thus, some studies have demonstrated that the CA3 protein is associated with intramuscular fat content ${ }^{(49)}$ and lipid accretion ${ }^{(50)}$, which agreed with our present results from correlation analysis. Consequently, an increase in CA3 abundance may be the factor for up-regulation of intramuscular fat levels in CLA-supplemented pigs.

In the present study, dietary CLA also decreased the relative abundance of proteins involved in fatty acid synthesis. The SCD plays a key role in regulating the synthesis of MUFA, especially oleate and palmitoleate. These two fatty acids are major MUFA components in membrane phospholipids, TAG, wax esters and cholesterol esters ${ }^{(51)}$. Growing evidence shows that dietary CLA affects the ratio of SFA to MUFA in skeletal muscle and adipose tissues $(7,8,11,12,52,53)$ due to the inhibition of desaturase. At present, there is limited information about SCD expression or activity in pig skeletal muscle, despite numerous studies of this gene in 3T3-L1 adipocytes ${ }^{(54)}$, mouse liver and isolated hepatic cells ${ }^{(55)}$, human HepG2 cells ${ }^{(56)}$ and human breast cancer cells $^{(57)}$. Moreover, a reduced SCD abundance was observed in 3T3-L1 cells by trans-10, cis-12 CLA after proteomics analysis ${ }^{(35)}$. In adipose tissue, depressed SCD enzyme activity was in part responsible for the depression of adiposity by $\mathrm{CLA}^{(58)}$. However, a role for SCD in muscle may be different from that in liver and adipose tissue. According to the idea of Doran et al. ${ }^{(59)}$, future studies are warranted to test the role of SCD in muscle and adipose tissue.

Another new and important observation from the present study is that dietary supplementation with CLA affected the expression of proteins related to the immune defence system (e.g. IL-4) and the nutrient transport system (e.g. albumin). For example, albumin would facilitate transport of LCFA to liver and muscle for oxidation and lipid synthesis, respectively. In addition, a reduction in IL-4 would attenuate inflammatory responses and, therefore, oxidative stress in tissues. This is expected to result in improved pork quality. However, spots (no. 39 and 31) named with albumin from rat and cat, respectively, and spots (no. 4 and 19) named with calsequestrin-2 (fragment) from pig had different abundance expression by dietary CLA. The difference may be derived from different sequence coverage to produce different entire amino acids composition between the protein spots with the same name. Furthermore, the spots with the same name exhibited different molecular weight and isoelectric point value.

In conclusion, dietary CLA enhanced the abundance of proteins related to energy metabolism, fatty acid oxidation and synthesis, amino acid metabolism, defence and transport. Increases in the abundance of CA3 and AST in Longissimus muscle may contribute to increased intramuscular fat content in finishing pigs.

\section{Acknowledgements}

There were no conflicts of interest in the present study. This research was supported by the National Natural Science Foundation of China (30400318) and the National '973' project of China (2004CB117500). We sincerely thank Guoyao Wu, Professor of Texas A\&M University, for help in the revision of our paper. W. Z. and Z. J. were responsible for experiment arrangement and for writing the manuscript. C. Z. was responsible for data analysis. Y. L., L. Y. and S. Z. were responsible for analysing the samples.

\section{References}

1. Pariza MW, Park Y \& Cook ME (2000) Mechanisms of action of conjugated linoleic acid: evidence and speculation. Proc Soc Exp Biol Med 223, 8-13.

2. Ostrowska E, Muralitharan M, Cross RF, et al. (1999) Dietary conjugated linoleic acids increase lean tissue and decrease fat deposition in growing pigs. J Nutr 129, 2037-2042.

3. Thiel-Cooper RL, Parrish FC Jr, Sparks JC, et al. (2001) Conjugated linoleic acid changes swine performance and carcass composition. J Anim Sci 79, 1821-1828.

4. Meadus WJ, Maclnnis R \& Dugan MER (2002) Prolonged dietary treatment with conjugated linoleic acid stimulates porcine muscle peroxisome proliferators activated receptor 
$\gamma$ and glutamine-fructose aminotransferase gene expression in vivo. J Mol Endocrinol 28, 79-86.

5. Wiegand BR, Sparks JC, Parrish FC, et al. (2002) Duration of feeding conjugated linoleic acid influences growth performance, carcass traits, and meat quality of finishing barrows. J Anim Sci 80, 637-643.

6. Tischendorf BF, Schöne F, Kirchheim U, et al. (2002) Influence of a conjugated linoleic acid mixture on growth, organ weights, carcass traits and meat quality in growing pigs. J Anim Physiol Anim Nutr 86, 117-128.

7. Sun DY, Zhu XP, Qiao SY, et al. (2004) Effects of conjugated linoleic acid levels and feeding intervals on performance, carcass traits and fatty acid composition of finishing barrows. Arch Anim Nutr 58, 277-286.

8. Jiang ZY, Zhong WJ, Zheng CT, et al. (2010) Conjugated linoleic acid differentially regulates fat deposition in backfat and longissimus muscle of finishing pigs. J Anim Sci $\mathbf{8 8}$, 1694-1705.

9. Ramsay TG, Evock-Clover CM, Steele NC, et al. (2001) Dietary conjugated linoleic acid alters fatty acid composition of pig skeletal muscle and fat. J Anim Sci 79, 2152-2161.

10. Gatlin LA, See MT, Larick DK, et al. (2002) Conjugated linoleic acid in combination with supplemental dietary fat alters pork fat quality. $J$ Nutr 132, 3105-3112.

11. Joo ST, Lee JI, Ha YL, et al. (2002) Effects of dietary conjugated linoleic acid on fatty acid composition, lipid oxidation, color, and water-holding capacity of pork loin. J Anim Sci 80, 108-112.

12. Corino C, Lo Fiego DP, Macchioni P, et al. (2007) Influence of dietary conjugated linoleic acids and vitamin $\mathrm{E}$ on meat quality, and adipose tissue in rabbits. Meat Sci 76, 19-28.

13. Dugan MER, Aalhus JL, Schaefer AL, et al. (1997) The effect of conjugated linoleic acid on fat to lean repartitioning and feed conversion in pigs. Can J Anim Sci 77, 723-725.

14. Wang JJ, Li DF, Dangott LJ, et al. (2006) Proteomics and its role in nutrition research. J Nutr 136, 1759-1762.

15. Wang JJ, Chen LX, Li DF, et al. (2008) Intrauterine growth restriction affects the proteomes of the small intestine, liver and skeletal muscle in newborn pigs. J Nutr 138, 60-66.

16. Hwang IH, Park BY, Kim JH, et al. (2005) Assessment of postmortem proteolysis by gel-based proteome analysis and its relationship to meat quality traits in pig longissimus. Meat Sci 69, 79-91.

17. Lametsch R, Kristensen L, Larsen MR, et al. (2006) Changes in the muscle proteome after compensatory growth in pigs. J Anim Sci 84, 918-924.

18. van de Wiel DFM \& Zhang WL (2007) Identification of pork quality parameters by proteomics. Meat Sci 77, 46-54.

19. Morzel M, Terlouw C, Chambon C, et al. (2008) Muscle proteome and meat eating qualities of longissimus thorscis of "Blonde d' Aquitaine" young bulls: a central role of HSP27 isoforms. Meat Sci 78, 297-304.

20. Milli A, Cecconi D, Campostrini N, et al. (2008) A proteomic approach for evaluating the cell response to a novel histone deacetylase inhibitor in colon cancer cells. Biochim Biophys Acta 1784, 1702-1710.

21. Sinha A, Srivastava N, Singh S, et al. (2009) Identification of differentially displayed proteins in cerebrospinal fluid of Parkinson's disease patients: a proteomic approach. Clin Chim Acta 400, 14-20.

22. Grider A, Mouat MF \& Scrimgeour AG (2007) Consumption of a moderately Zn-deficient and Zn-supplemented diet affects soluble protein expression in rat soleus muscle. J Nutr Biochem 18, 753-759.

23. Kharbanda KK, Vigneswara V, McVicker BL, et al. (2009) Proteomics reveal a concerted upregulation of methionine metabolic pathway enzymes, and downregulation of carbonic anhydrase-III, in betaine supplementated ethanolfed rats. Biochem Biophys Res Commun 381, 523-527.

24. Wang XQ, Ou DY, Yin JD, et al. (2009) Proteomic analysis reveals altered expression of proteins related to glutathione metabolism and apoptosis in the small intestine of zinc oxide-supplemented piglets. Amino Acids 37, 209-218.

25. NRC (1998) Nutrient Requirements of Swine, 10th ed. Washington, DC: National Academic Press.

26. AOAC (1995) Fat (Crude) in Meat and Meat Products (16th method 991.36). Arlington, VA: Association of Official Analytical Chemists.

27. Bradford MM (1976) A rapid and sensitive method for the quantitation of microgram quantities of protein utilizing the principle of protein-dye binding. Anal Biochem 72, 248-254.

28. Junghans P, Kaehne T, Beyer M, et al. (2004) Dietary proteinrelated changes in hepatic transcription correspond to modifications in hepatic protein expression in growing pigs. J Nutr 134, 43-47.

29. Xu Y, Tang Y \& Li Y (2008) Effect of folic acid on prenatal alcohol-induced modification of brain proteome in mice. BrJ Nutr 99, 455-461.

30. Jensen ON, Larsen MR \& Roepstorff P (1998) Mass spectrometric identification and microcharacterization of proteins from electrophoretic gels: strategies and applications. Proteins 33, 74-89.

31. Puente LG, Carrière JF, Kelly JF, et al. (2004) Comparative analysis of phosphoprotein-enriched myocyte proteomes reveals widespread alterations during differentiation. FEBS Lett 574, 138-144.

32. West DB, Delany JP, Camet PM, et al. (1998) Effects of conjugated linoleic acid on body fat and energy metabolism in the mouse. Am J Physiol 275, R667-R672.

33. West DB, Blohm FY, Truett AA, et al. (2000) Conjugated linoleic acid persistently increases total energy expenditure in $\mathrm{AKR} / \mathrm{J}$ mice without increasing uncoupling protein gene expression. J Nutr 130, 2471-2477.

34. Choi JS, Jung MH, Park HS, et al. (2004) Effect of conjugated linoleic acid isomers on insulin resistance and mRNA levels of genes regulating energy metabolism in high-fat-fed rats. Nutrition 20, 1008-1017.

35. Zhai J, Liu Z, Li J, et al. (2010) Different mechanisms of cis-9, trans-11 and trans-10, cis-12-conjugated linoleic acid affecting lipid metabolism in 3T3-L1 cells. J Nutr Biochem (Epublication ahead of print version 16 July 2010).

36. Hollung K, Grove H, Færgestad EM, et al. (2009) Comparison of muscle proteome profiles in pure breeds of Norwegian Landrace and Duroc at three different ages. Meat Sci 81, 487-492.

37. Abnous K \& Storey KB (2007) Regulation of skeletal muscle creatine kinase from a hibernating mammal. Arch Biochem Biophys 467, 10-19.

38. Barnes BR, Marklund S, Steiler TL, et al. (2004) The 5'-AMPactivated protein kinase $\gamma 3$ isoform has a key role in carbohydrate and lipid metabolism in glycolytic skeletal muscle. J Biol Chem 279, 38441-38447.

39. Birk JB \& Wojtaszewski JFP (2006) Predominant $\alpha 2 / \beta 2 / \gamma 3$ AMPK activation during exercise in human skeletal muscle. J Physiol 577, 1021-1032.

40. Schuck PF, Ferreira GC, Moura AP, et al. (2009) Mediumchain fatty acids accumulation in MCAD deficiency elicit lipid and protein oxidative damage and decrease non-enzymatic antioxidant defenses in rat brain. Neurochem Int $\mathbf{5 4}$, 519-525.

41. Peters JM, Park Y, Gonzalez FJ, et al. (2001) Influence of conjugated linoleic acid on body composition and target gene expression in peroxisome proliferators-activated receptor $\alpha$-null mice. Biochim Biophys Acta 1533, 233-242. 
42. Murase T, Aoki M \& Tokimitsu I (2005) Spplementation with $\alpha$-linoleic acid-rich diacylglycerol suppresses fatty liver formation accompanied by an up-regulation of $\beta$-oxidation in Zucker fatty rats. Biochim Biophys Acta 1733, 224-231.

43. Nall JL, Wu G, Kim KH, et al. (2009) Dietary supplementation of L-arginine and conjugated linoleic acid reduces retroperitoneal fat mass and increases lean body mass in rats. $J$ Nutr 139, 1279-1285.

44. Berk PD, Wada H, Horio Y, et al. (1990) Plasma membrane fatty acid-binding protein and mitochondrial glutamic-oxaloacetic transaminase of rat liver are related. Proc Natl Acad Sci U S A 87, 3484-3488.

45. Stump DD, Zhou SL \& Berk PD (1993) Comparison of plasma membrane FABP and mitochondrial isoform of aspartate aminotransferase from rat liver. Am J Physiol 265 , G894-G902.

46. Clarke DC, Miskovic D, Han XX, et al. (2004) Overexpression of membrane associated fatty acid binding protein (FABPpm) in vivo increases fatty acid sarcolemmal transport and metabolism. Genomics 17, 31-37.

47. Hauton D, Bennett MJ \& Evans RD (2001) Utilisation of Triacylglycerol and non-esterified fatty acid by the working rat heart: myocardial lipid substrate preference. Biochim Biophys Acta 1533, 99-109.

48. Koonen DPY, Glatz JFC, Bonen A, et al. (2005) Long-chain fatty acid uptake and FAT/CD36 translocation in heart and skeletal muscle. Biochim Biophys Acta 1736, 163-180.

49. Wang HL, Zhu ZM, Wang H, et al. (2006) Molecular characterization and association analysis of porcine CA3. Cytogenet Genome Res 115, 129-133.

50. Wu J, Zhou DH, Deng CY, et al. (2008) Expression pattern and polymorphism of three microsatellite markers in the porcine CA3 gene. Genet Sel Evol 40, 227-239.

51. Ntambi JM \& Miyazaki M (2004) Regulation of stearoyl-CoA desaturases and role in metabolism. Prog Lipid Res. 43, 91-104.
52. Corino C, Magni S, Pastorelli G, et al. (2003) Effect of conjugated linoleic acid on meat quality, lipid metabolism, and sensory characteristics of dry-cured hams from heavy pigs. J Anim Sci 81, 2219-2229.

53. Weber TE, Richert BT, Belury MA, et al. (2006) Evaluation of the effects of dietary fat, conjugated linoleic acid, and ractopamine on growth performance, pork quality, and fatty acid profiles in genetically lean gilts. J Anim Sci $\mathbf{8 4}$, 720-732.

54. Choi Y, Kim YC, Han YB, et al. (2000) The trans-10, cis-12 isomer of conjugated linoleic acid downregulated stearoylCoA desaturase 1 gene expression in 3T3-L1 adipocytes. J Nutr 130, 1920-1924.

55. Lee KN, Pariza MW \& Ntambi JM (1998) Conjugated linoleic acid decreases hepatic stearoyl-CoA desaturase mRNA expression. Biochem Biophys Res Commun 248, 817-821.

56. Choi Y, Park Y, Pariza MW, et al. (2001) Regulation of stearoyl-CoA desaturase activity by the trans-10, cis-12 isomer of conjugated linoleic acid in HepG2 cells. Biochem Biophys Res Commun 284, 689-693.

57. Choi Y, Park Y, Storkson JM, et al. (2002) Inhibiton of stearoyl-CoA desaturase activity by the cis-9, trans-11 isomer and the trans-10, cis-12 isomer of conjugated linoliec acid in MDA-MB-231 and MCF-7 human breast cancer cells. Biochem Biophys Res Commun 294, 785-790.

58. Smith SB, Hively TS, Cortese GM, et al. (2002) Conjugated linoleic acid depressed the $\Delta 9$ desaturase index and stearoyl coenzyme A desaturase enzyme activity in porcine subcutaneous adipose tissue. J Anim Sci 80, $2110-2115$.

59. Doran O, Moule SK, Teye GA, et al. (2006) A reduced protein diet induces stearoyl-CoA desaturase protein expression in pig muscle but not in subcutaneous adipose tissue: relationship with intramuscular lipid formation. $\mathrm{Br} J \mathrm{Nutr}$ 95, 609-617. 